\title{
IMMUNOMODULATION AND ANTIGENOTOXIC EFFECTS OF PROPOLIS IN PACLITAXEL-TREATED RATS
}

\author{
Samah M. Fathy ; ;oha I. Said \\ Zoology Department, Faculty of Science, Fayoum University, Fayoum, Egypt
}

\begin{abstract}
Article History:
Received: 31 October 2019

Revised: 28 November 2019

Accepted: 28 November 2019

Published Online:

5 December 2019
\end{abstract}

Keywords:

Inflammatory mediators

$N f-\kappa b$

Micronuclei

Paclitaxel

Propolis

*Correspondence:

Samah Fathy

Zoology Department

Faculty of Science

Fayoum University

Fayoum, Egypt

E-mail:

smm01@fayoum.edu.eg

\begin{abstract}
The current study aimed to investigate the potential immunomodulatory and antigenotoxic impacts of propolis in paclitaxel (PTX)-treated rats. Twenty four male Sprague Dawley rats were used in the present study and randomly/equally divided into four groups; control group, PTX group that was intraperitoneally injected with $5 \mathrm{mg} / \mathrm{kg}$ PTX (once/week), propolis group that received orally/daily $50 \mathrm{mg} / \mathrm{kg}$ propolis, and the last group received both PTX and propolis. All treatments were given for four weeks. The results showed a significant upregulation in the nuclear factor kappa B $(N f-\kappa b)$ gene expression in the spleen of PTX group, as compared with the control group. In addition, substantial increases in tumor necrosis factor- $\alpha$, interferon- $\gamma, \mathrm{C}-\mathrm{X}-\mathrm{C}$ motif ligand $10, \mathrm{CC}$ motif ligand 2 , and interleukin (IL)-4 concentrations, while a significant reduction in IL-10 concentration, were detected in the spleen of PTX group compared with the control group. Moreover, PTX resulted in a significant elevation in the frequency of micronucleated polychromatic erythrocytes in bone marrow cells compared with the control group. On the other hand, the treatment with propolis alone did not significantly affect all of these parameters, as compared with the control group. However, propolis decreased significantly all recorded side effects in the PTX-treated rats. In conclusion, propolis can be used as an adjunct with PTX to modulate the cytokines and chemokines release of splenic immune cells, as well as to counteract the genotoxic effect of PTX on bone marrow cells, through downregulating the splenic $N f$ - $\kappa b$ gene expression, and reducing the bone marrow micronuclei formation, respectively.
\end{abstract}

\section{INTRODUCTION}

Paclitaxel (PTX) is one of the most effective drugs used in chemotherapy. It exerts its effect by stabilizing microtubules during cell division, inhibiting spindle fiber formation thus arresting the cell cycle, and inducing cell death of tumor cells ${ }^{[1,2]}$. In the past decades, PTX has been widely used as an anticancer agent for the treatment of a wide variety of tumors such as breast, ovary, lung, colon, as well as head and neck cancers ${ }^{[3,4]}$. Since PTX cannot differentiate between normal and tumor cells, it has serious side effects including inflammatory disorders, 
hypersensitivity, and immunosuppression that severely limit its effectiveness ${ }^{[5]}$. In addition, PTX is one of the cytostatic drugs ${ }^{[6]}$ and its administration is accompanied by peripheral neuroinflammation, as a result of macrophage recruitment along with elevating release of various inflammatory mediators such as cytokines and chemokines ${ }^{[7,8]}$, as well as induction of micronucleus formation ${ }^{[9]}$.

Many transcription factors like nuclear factor kappa B (NF-kB) and cytokines such as tumor necrosis factor- $\alpha$ (TNF- $\alpha)$, interleukin(IL)-6, and IL-8 were proven to be vital mediators for inflammation-induced cancer cell proliferation, metastasis, invasion, angiogenesis, and apoptosis inhibition ${ }^{[10]}$. Noteworthy, $\mathrm{NF}-\kappa \mathrm{B}$ is a group of dimeric transcription factors that control different biological processes ${ }^{[11]}$. NF- $\kappa \mathrm{B}$ activation leads to upregulation of many genes, including those responsible for the production of proinflammatory cytokines like TNF- $\alpha^{[12-14]}$ and chemokines such as CC motif ligand 2 (CCL2) ${ }^{[15]}$. Besides, an in vivo enhanced antigen-specific interferon$\gamma\left(\right.$ IFN- $\gamma$-)-secreting CD8 ${ }^{+}$T-cells is ascribed to PTX treatment ${ }^{[16]}$. Consequently, nonpharmaceutical substances with antiinflammatory, antioxidant, and immunomodulatory properties, as well as with the ability to diminish the incidence of micronuclei formation may act as potential therapeutic agents to diminish the side effects of PTX.

Propolis is a resinous product of the honeybee, which is also known as bee glue with a wide range of biological activities including immunomodulatory, antitumor, and free radical scavenging activities ${ }^{[17-22]}$. Propolis has more than 300 constituents including; amino acids, phenolic acids, phenolic acid esters, flavonoids, cinnamic acid, terpenes, caffeic acid, volatile oils, aromatic acids, waxes, resins, balms, and pollen grains ${ }^{[23]}$. The different components of propolis vary according to the geographical regions, the vegetation from which the bee collects, and the species of bee that collect it. However, various studies have confirmed that wherever the region from which propolis originates, it exhibits similar properties $^{[23]}$. Two main immunopotent components have been identified in propolis; caffeic acid phenethyl ester (CAPE) and artepillin $C^{[17]}$. It has been reported that CAPE inhibits the secretion of IL- $1 \beta$ through the reduction of NF- $\kappa B$ activation, blocks the release of proinflammatory cytokines, increases the secretion of antiinflammatory cytokines, and diminishes the infiltration of inflammatory cells such as neutrophils and monocytes ${ }^{[17,24]}$. Propolis molecules were proven to exhibit a crucial immunomodulatory impact through inhibiting the release of various inflammatory cytokines/chemokines and NF- $\kappa \mathrm{B}$ activation, and exerts a substantial antigenotoxic impact via inhibition of the occurrence of micronuclei in cells of mice with Ehrlich ascites tumor ${ }^{[25,26]}$.

The current study aimed to investigate the potential modulatory effects of propolis, as a promising adjunct, against the side effects of the chemotherapeutic agent "PTX", with a special reference to the splenic inflammatory mediators and the micronucleus formation in the bone marrow of rats.

\section{MATERIAL AND METHODS Ethical statement}

The experimental techniques were carried out in agreement with the NIH (National Institutes of Health) guide for the care and use of laboratory animals, and were approved by the Local Committee of Animals Ethics of National Organization of Drug Control and Research (NODCAR), Egypt.

\section{Chemicals}

PTX ampules (100 mg/ampule) were purchased from local pharmacy in Egypt. It was produced by Corden Pharma Latina S.p.A. (Sermoneta, Latina, Italy) for BristolMyers Squibb Company (New York, NY, USA). Propolis capsules (400 mg/capsule) were obtained from Sigma Pharmaceutical Industries (Cairo, Egypt). 


\section{Experimental design}

Twenty four adult male Sprague Dawley rats (150-200 g) were randomly divided into four different groups $(n=6)$. (a) The control group, which intraperitoneally (i.p.) injected with $0.9 \%$ saline solution $(1.0 \mathrm{~mL} / \mathrm{kg}$ ) once/week for four weeks. (b) The PTX-treated group, which i.p. injected with PTX $(5 \mathrm{mg} / \mathrm{kg}$ diluted in $1.0 \mathrm{~mL} 0.9 \%$ saline solution) once/week for four weeks ${ }^{[27]}$. (c) The propolis-treated group, which orally supplemented with propolis $(50 \mathrm{mg} / \mathrm{kg} /$ day in $1.0 \mathrm{~mL}$ distilled water) for four weeks ${ }^{[28]}$. (d) The PTX + propolis-treated animals, which received both PTX and propolis, concurrently, as indicated above for four weeks.

\section{Tissue samples' collection}

At the end of the experiment, animals were anesthetized using xylazine/ketamine anesthesia and decapitated. The spleen and femur were removed and rinsed in icecold phosphate buffered saline $(0.1 \mathrm{~mol}$, $\mathrm{pH}$ 7.4). The spleen was weighed before homogenization and divided into two parts. The first part was homogenized in phosphate buffer saline (PBS) and sonicated for the enzyme-linked immunosorbent assay (ELISA). Thereafter, the homogenates were centrifuged for 5 minutes at $5000 \times g$ at $4^{\circ} \mathrm{C}$ and the supernatant was stored at $\leq-20^{\circ} \mathrm{C}$ for determination of cytokines and chemokines' levels. The amount of protein was measured in the homogenates according to the Bradford method ${ }^{[29]}$ by using the BioRad protein assay kit (Hercules, CA, USA). The second part was kept in RNA lysis solution for determination of gene expression of rat $N f-\kappa b$. Samples of bone marrow were collected from femur for micronucleus test.

\section{Estimation of splenic inflammatory mediators}

The levels of TNF- $\alpha$, IFN- $\gamma$, IL-4, IL-10, $\mathrm{C}-\mathrm{X}-\mathrm{C}$ motif ligand 10 (CXCL10), and CCL2 were estimated in the supernatant of spleen tissue by sandwich ELISA kits specific for rats (Merck Millipore, San
Francisco, California, USA) following the manufacturer's instruction. The absorbance was measured at $450 \mathrm{~nm}$ with a Dynatech MR7000 microplate reader (Dynex Technologies Inc., Chantilly, VA, USA).

Determination of $N f-\kappa b$ gene expression by real-time (quantitative) polymerase chain reaction (qPCR) assay

Total RNA isolation and gPCR were done according to Lee et al. $^{[30]}$ by using SV Total RNA Isolation System (Promega Corporation, Madison, WI, USA) and Applied Biosystems StepOne ${ }^{\mathrm{TM}}$ (Applied Biosystems, Foster City, CA, USA), respectively. The absorbance at $260 \mathrm{~nm}$ and $280 \mathrm{~nm}$ was used to assess the purity of RNA samples and measured by NanoDrop ${ }^{\mathrm{TM}}$ 2000c Spectrophotometer (Thermo Fisher Scientific, Waltham, MA, USA). RNA samples are considered pure when the $260 / 280$ ratio values are $\sim 2.0$. The relative levels of rat $N f-\kappa b$ mRNA (forward primer: 5'-CCTCCTCCACCCTACCAAGT3', reverse primer: 5'-CACCCAAAGTGC TTCAGTCA-3', 199 base pairs) were normalized based on the house keeping gene "glyceraldehyde 3-phosphate dehydrogenase (GAPDH)".

\section{Micronucleus test}

Two slides of bone marrow smears were prepared for each animal and stained with May-Grünwald-Giemsa according to Schmid $^{[31]}$. Two thousands polychromatic erythrocytes (PCEs) were recorded per animal and the number of micronucleated polychromatic erythrocytes (MNPCEs) was counted. The analysis of slides was carried out blindly using a light microscope with a $100 x$ immersion objective. Data were expressed as mean of MNPCEs' percentages \pm standard deviation.

\section{Statistical methods}

Data were expressed as means \pm standard deviation. The statistical analysis was performed by the one-way analysis of variance (ANOVA). The significant differences among groups were determined by Duncan's multiple range test at $5 \%$ level 
using statistical package for social science (SPSS 17, SPSS Inc. Chicago, IL, USA). Value of $P<0.05$ among groups was considered statistically significant.

\section{RESULTS}

Effects of propolis on the levels of cytokines and chemokines in the spleen of the PTX-treated rats

The levels of TNF- $\alpha$, IFN- $\gamma$, IL-4, CXCL10, and CCL2 elevated significantly $(P<0.05)$, while the IL-10 level decreased significantly $(P<0.05)$ in the spleen of the PTX (alone)-treated group when compared with the control and the propolis (alone)treated groups (Table 1). However, no remarkable difference in the production of these cytokines and chemokines was recorded between the propolis (alone)treated group and the control group $(P>0.05)$. By treating rats with PTX and propolis together, the levels of spleen TNF- $\alpha, \quad$ IFN- $\gamma, \quad$ IL-4, CXCL10, and CCL2 were substantially reduced $(P<0.05)$ when compared with their levels in the PTX (alone)-treated group, but still elevated significantly $(P<0.05)$ when compared with the control group (Table 1). On the contrary, the production of the antiinflammatory cytokine "IL-10" substantially augmented $(P<0.05)$ in the spleen of the group treated with PTX + propolis, as compared with the PTX (alone)-treated group, but still remained significantly lower $(P<0.05)$ than its level in the control group (Table 1).

Table 1: Effect of paclitaxel (PTX), propolis, and PTX + propolis treatments on cytokines and chemokines' levels of rat spleen.

\begin{tabular}{lcccccc}
\hline & TNF- $\alpha$ & IL-4 & $\begin{array}{c}\text { IL-10 } \\
(\mathrm{pg} / \mathrm{mg} \text { protein })\end{array}$ & CXCL10 & CCL2 \\
\cline { 2 - 7 } Control & $27.0 \pm 1.8$ & $19.6 \pm 1.0$ & $143.5 \pm 1.5$ & $26.4 \pm 2.5$ & $48.8 \pm 2.0$ & $18.2 \pm 5.8$ \\
PTX & $115.0 \pm 4.8^{\mathrm{a}}$ & $37.5 \pm 1.7^{\mathrm{a}}$ & $54.2 \pm 1.5^{\mathrm{a}}$ & $116.3 \pm 2.8^{\mathrm{a}}$ & $134.5 \pm 25.2^{\mathrm{a}}$ & $111.9 \pm 1.1^{\mathrm{a}}$ \\
Propolis & $29.5 \pm 2.4^{\mathrm{b}}$ & $16.3 \pm 0.8^{\mathrm{b}}$ & $140.6 \pm 1.8^{\mathrm{b}}$ & $30.2 \pm 1.6^{\mathrm{b}}$ & $50.3 \pm 1.9^{\mathrm{b}}$ & $17.7 \pm 1.2^{\mathrm{b}}$ \\
PTX + Propolis & $63.5 \pm 7.8^{\mathrm{ab}}$ & $27.1 \pm 1.5^{\mathrm{ab}}$ & $99.8 \pm 3.4^{\mathrm{ab}}$ & $66.6 \pm 4.4^{\mathrm{ab}}$ & $86.5 \pm 2.8^{\mathrm{ab}}$ & $75.1 \pm 1.6^{\mathrm{ab}}$ \\
\hline
\end{tabular}

The data are expressed as mean \pm standard deviation $(n=6)$. CCL: CC motif ligand, CXCL: C-X-C motif ligand, IFN: interferon, IL: interleukin, TNF: tumor necrosis factor. ${ }^{\mathrm{a}} P<0.05$ data are statistically significant versus control rats, ${ }^{\mathrm{b}} P<0.05$ data are statistically significant versus PTX-treated rats.

Effect of propolis on the $N f-\kappa b$ gene expression in the spleen of the PTXtreated rats

The current study demonstrated that PTX injection upregulated significantly $(P<0.05)$ the splenic $N f$ - $\kappa b$ gene expression, as compared with the control and the propolis (alone)-treated groups (Figure 1). On the other hand, the treatment with propolis alone did not induced a significant difference $(P>0.05)$ in the splenic $N f-\kappa b$ gene expression, as compared with the control group. By treating animals with
PTX + propolis, the $N f-\kappa b$ gene expression was remarkably reduced, as compared with the PTX (alone)-treated animals $(P<0.05)$. Meanwhile, its expression in the group treated with PTX + propolis was still significantly higher $(P<0.05)$ than its expression in the control group (Figure 1).

Effect of propolis on the frequency of bone marrow micronuclei formation in the PTX-treated rats

Figure "2" showed one normochromatic erythrocyte and one MNPCE with one 
micronucleus in the bone marrow cells of rat. The treatment with PTX increased significantly $(P<0.05)$ the percentage of MNPCEs when compared with the control and the propolis (alone)-treated groups (Table 2). On the other hand, the treatment of rats with propolis alone did not significantly alter the frequency of MNPCEs in rat bone marrow cells compared with the control rats $(P>0.05)$.

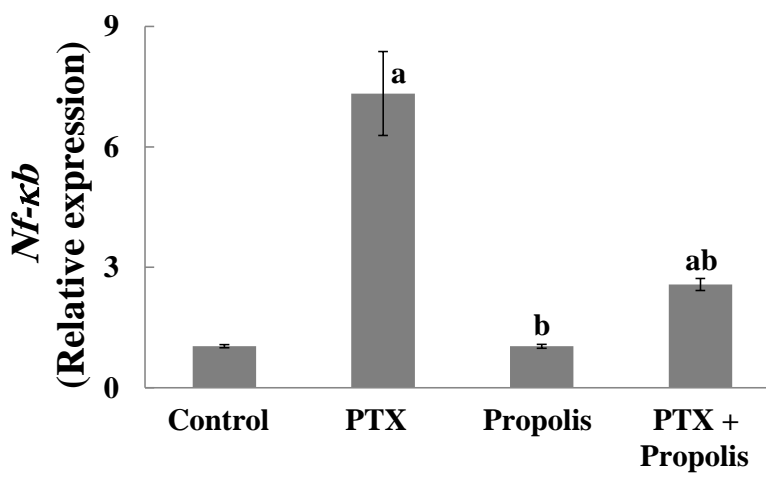

Figure 1: Effect of paclitaxel (PTX), propolis, and PTX + propolis treatments on $N f-\kappa b$ gene expression of rat spleen. The data are expressed as mean \pm standard deviation (n = 6). ${ }^{\mathrm{a}} P<0.05$ data are statistically significant versus control rats, ${ }^{\mathrm{b}} P<0.05$ data are statistically significant versus PTXtreated rats.

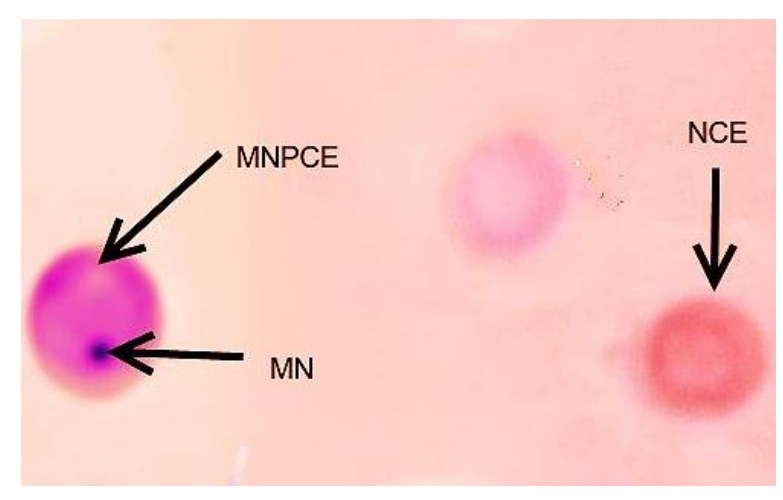

Figure 2: Photomicrographs showing a normochromatic erythrocyte (NCE), and a micronucleated polychromatic erythrocyte (MNPCE) with one micronucleus (MN) in the bone marrow cells of rat.

Administration of propolis along with PTX caused a significant decrease in the percentage of MNPCEs, as compared with the PTX (alone)-treated group $(P<0.05)$. In spite of this decrement in the percentage of MNPCEs, it was still significantly higher $(P<0.05)$ than the normal values of the control group (Table 2).

\section{DISCUSSION}

Various reviews indicate collaboration between conventional chemotherapeutic agents and immunotherapy. That reinforcement is facilitated via different mechanisms such as the release of inflammatory cytokines $^{[32]}$ and induced immunogenicity to tumors treated with chemotherapy ${ }^{[33]}$. Chemotherapy is a double-edged sword that exhibits its anticancer effect as a result of its cytotoxic impact, while the cytotoxicity effect of the chemotherapeutic agents was reported to influence multiple organs apart from the tumor ${ }^{[34]}$. PTX is a cytostatic agent that was selected to treat solid tumors ${ }^{[35]}$. Nevertheless, PTX treatment was accompanied by several adverse reactions such as myelosuppression, immunosuppression, kidney damage, peripheral neurotoxicity, bone marrow suppression, as well as micronucleus formation ${ }^{[10]}$.

The present research revealed that the $N f-\kappa b$ gene expression in the spleen tissues was significantly induced in PTXtreated rats; and that upregulation was reversed by propolis. In addition, the levels of TNF- $\alpha$, IFN- $\gamma$, and IL-4 increased significantly, while the antiinflammatory cytokine "IL-10" level diminished significantly in the spleen tissues of PTX-injected group; all of the above PTX effects were modulated in the presence of propolis. The overexpression of $N f-\kappa b$ gene in the current experiment is in consistent with Wang et al. ${ }^{[36]}$, who demonstrated that PTX managed to induce $N f-\kappa b$ gene expression, which controlling cell survival, proliferation, invasion and metastasis $^{[37]}$. It has also been reported that $N F-\kappa B$ gene expression is ascribed with the inflammatory situation ${ }^{[38]}$. Therefore, it is a vital key target for mitigation of inflammation. 
Table 2: Effect of treatment with propolis on the frequency of bone marrow micronuclei formation in PTX-treated rats.

\begin{tabular}{lccc}
\hline & $\begin{array}{c}\text { Number of } \\
\text { examined cells }\end{array}$ & $\begin{array}{c}\text { Number of } \\
\text { MNPCEs/1000PCEs }\end{array}$ & $\begin{array}{c}\text { MNPCEs \% } \\
\text { (mean } \pm \text { standard deviation) }\end{array}$ \\
\cline { 2 - 4 } Control & 4.3 & $0.43 \pm 0.05$ \\
PTX & 12000 & 30.6 & $3.03 \pm 0.32^{\mathrm{a}}$ \\
Propolis & 6.3 & $0.65 \pm 0.17^{\mathrm{b}}$ \\
PTX + Propolis & & 19.6 & $1.98 \pm 0.13^{\mathrm{ab}}$ \\
\hline
\end{tabular}

MNPCEs: micronucleated polychromatic erythrocytes, PCEs: polychromatic erythrocytes. ${ }^{\mathrm{a}} P<0.05$ data are statistically significant versus control rats, ${ }^{\mathrm{b}} P<0.05$ data are statistically significant versus PTX-treated rats.

Besides, NF- $\kappa \mathrm{B}$ activation is achieved as a result of proinflammatory cytokines through I $\mathrm{B}$ kinase (IKK) complex induction $^{[39]}$, as endotoxin, carcinogen, ionizing radiation, and free radical. Moreover, NF- $\kappa \mathrm{B}$ activation is responsible for the release of proinflammatory cytokines $^{[14]}$ and chemokines ${ }^{[40]}$ in different cell types. Consequently, the elevated levels of TNF- $\alpha$ and IFN- $\gamma$ can be induced via $\mathrm{NF}-\kappa \mathrm{B}$ activation and is attributed to the upregulation of $N F-\kappa B$ gene expression ${ }^{[41]}$. It has been reported that the levels of TNF- $\alpha$ and IFN- $\gamma$ increased in the spinal cord of male C57BL/6J mice following PTX treatment $^{[42]}$. Noteworthy, IFN- $\gamma$ is one of the cytokines, which is responsible for activation of signal transducer and activator of transcription 3 (STAT3) homodimers and secretion of both proinflammatory and antiinflammatory cytokines ${ }^{[43]}$. Moreover, there is a tendency towards promotion of NF- $\kappa \mathrm{B}$ pathway, secretion of more T-helper-1 cytokines such as TNF- $\alpha$ and IFN- $\gamma$, and less production of T-helper- 2 cytokines such as IL-10, which is ascribed for better antitumor response ${ }^{[44]}$. The elevated release of IL-4 may ascribe with the temporary modulation of the immune response that is sometimes linked with the chemotherapy to reinforce additional immunotherapeutic and vaccination trials for cancer treatment ${ }^{[45]}$. Intriguingly, IL-4 cytokine was proven to exert paradoxical, pro- or anti-inflammatory, effects on the developing immune response depending on various factors such as the primary target cell for this cytokine during immune reaction ${ }^{[46]}$. Hence, it can be deduced that the elevation in the release of the proinflammatory cytokines and the reduction in the IL-10 secretion shown in the current study in the spleen tissue of rats were due to the upregulation of $N f-\kappa b$ gene expression following PTX injection. The previous findings along with our findings confirm the role of NF- $\kappa \mathrm{B}$ in inflammation, and the use of natural adjuncts that are able to target this gene can modulate the toxic effects of PTX in spleen. Current study showed that propolis downregulated $N f-\kappa b$ gene expression, as well as reduced the levels of TNF- $\alpha$, IFN- $\gamma$, and IL-4, while it elevated the secretion of IL-10 in spleen tissue of PTX-treated rats. This modulation control of propolis is in agreement with Tiveron et al. ${ }^{[47]}$, who demonstrated that low concentrations of propolis reduced NF- $\kappa \mathrm{B}$ activation and decreased TNF- $\alpha$ secretion in RAW 264.7 macrophages as a result of its anti-inflammatory and immunomodulatory impacts.

The levels of CXCL10 and CCL2 elevated in PTX group, while propolis reduced the release of the previously mentioned mediators by PTX. It has been reported that gene expression of CXCL10, which is also known as interferon gammainduced protein 10, was induced by PTX 
in DA-3 breast cancer cell line ${ }^{[48]}$. It has been shown that upregulation of IFN- $\gamma$ pathway is accompanied by increasing the expression of IFN- $\gamma$ inducible gene "CXCL10" in the spleen ${ }^{[49]}$. Moreover, CXCL10 is also one of the targets for $\mathrm{NF}-\kappa \mathrm{B} 2$ transcript $^{[12]}$ and the injection with PTX could elevate expression of $N F-\kappa B$ gene, nuclear transition, and consequently can combine with the CXCL10 promoter to induce the expression of CXCL10 gene along with the increase in CXCL10 chemokine secretion ${ }^{[50]}$. Regarding the chemokine CCL2, the current result was in line with Makker et al. ${ }^{[42]}$, who showed an increased level of CCL2 in dorsal root ganglia of PTX-treated male C57BL/6J mice. It was demonstrated that $\mathrm{NF}-\kappa \mathrm{B}$ is a crucial transcription factor for CCL2 gene expression and subsequently for CCL2 release $^{[13]}$. Consequently, propolis can modulate PTX effects via inhibition of rat $N f-\kappa b$ gene expression and a subsequent reduction of proinflammatory cytokines and chemokines, as well as augmentation of IL-10 release.

PTX is a genotoxic agent as indicated by the significant increase in the number of MNPCEs when compared with the control group. These results are in agreement with the reported genotoxicity of PTX by several authors, both in vitro ${ }^{[51]}$ and in vivo ${ }^{[52]}$. Digue et al. ${ }^{[53]}$ stated that PTX showed a strong aneugenic effect in vitro in normal human T-lymphocytes at therapeutic doses. Moreover, the genotoxic potential of the PTX was confirmed in mammalian cells using the mouse bone marrow micronucleus assay ${ }^{[54,55]}$. Micronucleus is formed during anaphase from lagging acentric chromosome or chromatid fragments caused by chromosomal breaks or due to nondisjunction of chromosomes as a result of dysfunctional spindle apparatus. This in turn explains the genotoxic potential of PTX since its mechanism of action includes disturbances in microtubule assembly and results in disruption of mitotic spindle formation, obstruction of cell cycle progression in late Gap 2-mitotic phases ${ }^{[56]}$, as well as induction of DNA single strand breaks $^{[53]}$. The PTX has been reported to induce oxidative DNA damage by generating increased levels of reactive oxygen species and altering the mitochondrial membrane permeability ${ }^{[57]}$. The protective effect of propolis against PTX-induced chromosomal damage was indicated by the reduction in the number of MNPCEs. However, this decrement did not return the number of MNPCEs down to the control value. Our results confirmed the antigenotoxic effects of propolis that have been previously reported $^{[58,59]}$. In addition, Padmavathi et $a l{ }^{[60]}$ studied the synergistic effects of propolis with PTX by using a 7,12-dimethylbenz[a]anthracene-induced breast cancer rat model; and it was found that the combined intake of PTX and propolis achieved the lowest tumor weight compared with those with either PTX or propolis alone. The propolis may also protect against PTXinduced DNA damage due to its free radical scavenging potency without affecting PTX antitumor activity ${ }^{[61]}$.

In a nutshell, PTX injection upregulated rat $N f$ - $\kappa b$ gene expression, which in turn increased the secretion of the cytokines "TNF- $\alpha$, IFN- $\gamma$, and IL- 4 " and chemokines "CXCL10 and CCL2", and decreased IL-10 level. Propolis showed immunomodulation impact against PTX effects through inhibition of $N f-\kappa b$ gene expression in the spleen of rat. Moreover, propolis was capable of modulating the genotoxic effect of PTX via inhibition of micronuclei formation in the rats' bone marrow cells.

\section{ACKNOWLEDGMENTS}

The authors thank Dr. Areeg Mohamed Abdelrazek (Physiology Department, National Organization for Drug Control and Research "NODCAR" Giza, Egypt) for her technical support. This research received no specific grant from any funding agency in the public, commercial or not-forprofit sectors. The authors have no potential financial conflict of interest. 


\section{AUTHORS' CONTRIBUTIONS}

Both SMF and NIS planned the study and designed all experiments, carried out the experiments and performed the statistical analysis, summarized, discussed and interpreted the results, and drafted the manuscript.

\section{REFERENCES}

[1] Kavallaris, M. (2010). Microtubules and resistance to tubulin-binding agents. Nat Rev Cancer, 10: 194-204.

[2] Rao, C. V.; Kurkjian, C. D. and Yamada, H. Y. (2012). Mitosistargeting natural products for cancer prevention and therapy. Curr Drug Targets, 13: 1820-1830.

[3] Bansal, A.; Kapoor, D. N.; Kapil, R. et al. (2011). Design and development of paclitaxel-loaded bovine serum albumin nanoparticles for brain targeting. Acta Pharm, 61: 141-156.

[4] Wilson, L. and Jordan, M. A. (2004). New microtubule/tubulin-targeted anticancer drugs and novel chemotherapeutic strategies. J Chemother, 16(4): 83-85.

[5] Feio, D. C. A.; de Oliveira, N. C. L.; Pereira, E. L. R. et al. (2017). Organic effects of associating paclitaxel with a lipid-based nanoparticle system on a nonhuman primate, Cebus paella. Int J Nanomedicine, 12: 3827-3837.

[6] Johnston, G.D. (2000). Positive inotropic drugs and drugs used in dysrhythmias. In: Meyler's Side Effects of Drugs (Dukes M. N. G. and Aronson J. K., eds), pp. 523-574. Elsevier, Amsterdam, Netherlands.

[7] Brandolini, L.; d'Angelo, M.; Antonosante, A. et al. (2019). Chemokine signaling in Chemotherapy-induced neuropathic pain. Int J Mol Sci, 20(12): E2904 (DOI: 10.3390/ijms20122904).

[8] Naguib, M.; Xu, J. J.; Diaz, P. et al. (2012). Prevention of paclitaxelinduced neuropathy through activation of the central cannabinoid type 2 receptor system. Anesth Analg, 114(5): 1104-1120.

[9] Rezaee, R.; Monemi, A.; SadeghiBonjar, M. A. et al. (2019). Berberine alleviates paclitaxel-induced neuropathy. J Pharmacopuncture, 22: 90-94.

[10] Kunnumakkara, A. B.; Sailo, B. L.; Banik, K. et al. (2018). Chronic diseases, inflammation, and spices: how are they linked? J Transl Med, 16: 14 (DOI: 10.1186/s12967-0181381-2).

[11] Vaughan, C.; Mohanraj, L.; Singh, S. et al. (2011). Human oncoprotein MDM2 up-regulates expression of NF-кB2 precursor p100 conferring a survival advantage to lung cells. Genes Cancer, 2(10): 943-955.

[12] Martins, G. R.; Gelaleti, G.B.; Moschetta, M. G. et al. (2016). Proinflammatory and anti-inflammatory cytokines mediated by $\mathrm{NF}-\kappa \mathrm{B}$ factor as prognostic markers in mammary tumors. Mediators Inflamm, 2016: $9512743 \quad$ (DOI: 10.1155/2016/ 9512743).

[13] Tan, B. L. and Norhaizan, M. E. (2019). Curcumin combination chemotherapy: the implication and efficacy in cancer. Molecules, 24(14): E2527 (DOI: 10.3390/molecules 24142527).

[14] Zaczyńska, E.; Czarny, A.; Jankowska, E. A. et al. (2007). NF- $\kappa B$ expression in mononuclear cells from patients with chronic heart failure observed in endotoxin tolerance. CentralEuropean Journal of Immunology, 32(4): 206-211.

[15] Funakoshi-Tago, M.; Ohsawa, K.; Ishikawa, T. et al. (2016). Inhibitory effects of flavonoids extracted from Nepalese propolis on the LPS signaling pathway. Int Immunopharmacol, 40: 550-560.

[16] Pfannenstiel, L. W.; Lam, S. S.; Emensa, L. A. et al. (2010). Paclitaxel enhances early dendritic cell maturation and function through 
TLR4 signaling in mice. Cell Immunol, 263: 79-87.

[17] Zaccaria, V.; Curti, V.; Di Lorenzo, A. et al. (2017). Effect of green and brown propolis extracts on the expression levels of microRNAs, mRNAs and proteins, related to oxidative stress and inflammation. Nutrients, 9(10): 1090 (DOI: 10.3390/ nu9101090).

[18] Funakoshi-Tago, M.; Okamoto, K.; Izumi, R. et al. (2015). Antiinflammatory activity of flavonoids in Nepalese propolis is attributed to inhibition of the IL-33 signaling pathway. Int Immunopharmacol, 25: 189-198.

[19] Sforcin, J. M. (2016). Biological properties and therapeutic applications of propolis. Phytother Res, 30: 894905.

[20] Orsolić, N. and Basic, I. (2003): Immunomodulation by water-soluble derivative of propolis: a factor of antitumor reactivity. J. Ethnopharmacol, 84: 265-273.

[21] Gul Baykalir, B.; Tatli Seven, P.; Gur, S.; et al. (2016). The effects of propolis on sperm quality, reproductive organs and testicular antioxidant status of male rats treated with cyclosporine-A. Anim Reprod (Belo Horizonte), 13(2): 105-111.

[22] Sawicka, D.; Car, H.; Borawska, M. H. et al. (2012). The anticancer activity of propolis. Folia Histochem Cytobiol, 50: 25-37.

[23] Kosalec, I.; Pepeljnjak, S.; Bakmaz, M. et al. (2005). Flavonoid analysis and antimicrobial activity of commercially available propolis products. Acta Pharm, 55(4): 423-430.

[24] Rajoo, M.; Parolia, A.; Pau, A. et al. (2014). The role of propolis in inflammation and orofacial pain: a review. Annual Research \& Review in Biology, 4: 651-664.

[25] Franchin, M.; Freires, I. A.; Lazarini, J. G. et al. (2018). The use of Brazilian propolis for discovery and development of novel antiinflammatory drugs. Eur J Med Chem, 153: 49-55.

[26] Oršolić, N.; Car, N.; Lisičić, D. et al. (2013). Synergism between propolis and hyperthermal intraperitoneal chemotherapy with cisplatin on Ehrlich ascites tumor in mice. J Pharm Sci, 102: 4395-4405.

[27] Shord, S. S. and Camp, J. R. (2006). Intravenous administration of paclitaxel in Sprague-Dawley rats: what is a safe dose? Biopharm Drug Dispos, 27(4): 191-96.

[28] El-Masry, T. A.; Emara, A. M.; El-Shitany, N. A. (2011). Possible protective effect of propolis against lead-induced neurotoxicity in animal model. J Evol Biol Res, 3: 4-11.

[29] Bradford, M. M. (1976). A rapid and sensitive method for the quantitation of microgram quantities of protein utilizing the principle of protein-dye binding. Anal Biochem, 72: 248-254.

[30] Lee, C. G.; Kim, Y. W.; Kim, E. H. et al. (2012). Farnesoid X receptor protects hepatocytes from injury by repressing miR-199a-3p, which increases levels of LKB1. Gastroenterology, 142: 1206-1217.

[31] Schmid, W. (1975). The micronucleus test. Mutat Res, 31: 9-15.

[32] Asavaroengchai, W.; Kotera, Y.; Mulé, J. J. (2002). Tumor lysatepulsed dendritic cells can elicit an effective antitumor immune response during early lymphoid recovery. PNAS, 99(2): 931-936.

[33] Michaud, M.; Martins, I.; Sukkurwala, A. Q. et al. (2011). Autophagydependent anticancer immune responses induced by chemotherapeutic agents in mice. Science, 334: 1573-1577.

[34] Chang, Y. S.; Jalgaonkar, S. P.; Middleton, J. D.; et al. (2017). Stressinducible gene Atf3 in the noncancer host cells contributes to chemotherapyexacerbated breast cancer metastasis. PNAS, 114(34): E7159-E7168. 
[35] Wani, M. C.; Taylor, H. L.; Wall, M. E. et al. (1971). Plant antitumor agents. VI. The isolation and structure of taxol, a novel antileukemic and antitumor agent from Taxus brevifolia. J Am Chem Soc, 93: 2325-2327.

[36] Wang, Y.; Zhang, C.; Zhang, S. et al. (2017). Kanglaite sensitizes colorectal cancer cells to taxol via $\mathrm{NF}-\kappa \mathrm{B}$ inhibition and connexin 43 upregulation. Sci Rep, 7: 1280 (DOI: 10.1038/s41598-017-01480-2).

[37] Huang, Y. and Fan, W. (2002). IkappaB kinase activation is involved in regulation of paclitaxel-induced apoptosis in human tumor cell lines. Mol Pharmacol, 61: 105-113.

[38] Fathy, S. M. and Drees, E. A. (2016). Protective effects of Egyptian cloudy apple juice and apple peel extract on lipid peroxidation, antioxidant enzymes and inflammatory status in diabetic rat pancreas. BMC Complem Alter Med, 16: 8 (DOI: 10.1186/ s12906-015-0957-0).

[39] Karin, M. (2008). The IkappaB kinase - a bridge between inflammation and cancer. Cell Res, 18: 334-342.

[40] Li, Q. and Verma, I. M. (2002). NF-kappa B regulation in the immune system. Nat Rev Immunol, 2: 725-734.

[41] Taniguchi, K. and Karin, M. (2018). $\mathrm{NF}-\kappa \mathrm{B}$, inflammation, immunity and cancer: coming of age. Nat Rev Immunol, 18: 309-324.

[42] Makker, P. G.; Duffy, S. S.; Lees, J. G. et al. (2017). Characterisation of immune and neuroinflammatory changes associated with chemotherapy-induced peripheral neuropathy. PLoS ONE, 12 (1): e0170814 (DOI: 10.1371/journal.pone.0170814).

[43] González-Navajas, J. M.; Lee, J.; David, M. et al. (2012). Immunomodulatory functions of type I interferons. Nat Rev Immunol, 12(2): 125-135.

[44] Chambers, W. H.; Rabinowich, H. and Herberman, R. B. (2003). Mechanisms of immunosuppression. In: Holland-
Frei Cancer Medicine (Kufe, D. W.; Pollock, R. E.; Weichselbaum, R. R. et al., eds). BC Decker Inc., Hamilton, ON, Canada.

[45] Weir, G. M.; Liwski, R. S. and Mansour, M. (2011). Immune modulation by chemotherapy or immunotherapy to enhance cancer vaccines. Cancers (Basel), 3(3): 31143142.

[46] Biedermann, T. and Röcken, $M$. (2005). Pro- and anti-inflammatory effects of IL-4: from studies in mice to therapy of autoimmune diseases in humans. Ernst Schering Res Found Workshop, (50): 235-242.

[47] Tiveron, A. P.; Rosalen, P. L.; Franchin, M. et al. (2016). Chemical characterization and antioxidant, antimicrobial, and anti-Inflammatory activities of south Brazilian organic propolis. PLoS ONE, 11(11): e0165588 (DOI: 10.1371/journal.pone. 0165588).

[48] Zaks-Zilberman, M.; Zaks, T. Z.; Vogel, S. N. (2001). Induction of proinflammatory and chemokine genes by lipopolysaccharide and paclitaxel (taxol) in murine and human breast cancer cell lines. Cytokine, 15(3): 156165.

[49] Prencipe, G.; Caiello, I., Pascarella, A. et al. (2018). Neutralization of IFN- $\gamma$ reverts clinical and laboratory features in a mouse model of macrophage activation syndrome. J Allergy Clin Immunol, 141(4): 1439-1449.

[50] Feng, R.; Morine, Y.; Ikemoto, T. et al. (2018). Nab-paclitaxel interrupts cancer-stromal interaction through C-X-C motif chemokine 10-mediated interleukin-6 downregulation in vitro. Cancer Sci, 109: 2509-2519.

[51] Turkez, H.; Tatar, A.; Hacimuftuoglu, A. et al. (2010). Boric acid as a protector against paclitaxel genotoxicity. Acta Biochim Pol, 57: 95-97.

[52] AL-Sharif, M. M. Z. (2012). Studies on the genotoxic effects of anticancer 
drug paclitaxel (taxol) in mice. World Appl Sci J, 16(7): 989-997.

[53] Digue, L.; Orsière, T.; De Méo, M. et al. (1999). Evaluation of the genotoxic activity of paclitaxel by the in vitro micronucleus test in combination with fluorescent in situ hybridization of a DNA centromeric probe and the alkaline single cell gel electrophoresis technique (comet assay) in human T-lymphocytes. Environ Mol Mutagen, 34: 269-278.

[54] Tinwell, H. and Ashby, J. (1994). Genetic toxicity and potential carcinogenicity of taxol. Carcinogenesis, 15: 1499-1501.

[55] Jagetia, G. C. and Nayak, V. (1996). Treatment of mice with a novel antineoplastic agent taxol before irradiation increases the frequency of micronuclei in the bone marrow. Mutat Res, 349: 219-227.

[56] Schiff, P. B. and Horwitzf, S. B. (1980). Taxol stabilizes microtubules in mouse fibroblaat cells. PNAS, 77: 1561-1565.

[57] Ramanathan, B.; Jan, K. Y.; Chen, C. $\mathrm{H}$. et al. (2005). Resistance to paclitaxel is proportional to cellular total antioxidant capacity. Cancer Res, 65(18): 8455-8460.

[58] Roberto, M. M.; Jamal, C. M.; Malaspina, O. et al. (2016). Antigenotoxicity and antimutagenicity of ethanolic extracts of Brazilian green propolis and its main botanical source determined by the Allium cepa test system. Genet Mol Biol, 39(2): 257269.

[59] Kumari, S.; Naik, P.; Vishma, B. L. et al. (2016). Mitigating effect of Indian propolis against mitomycin $\mathrm{C}$ induced bone marrow toxicity. Cytotechnology, 68(5): 17891800.

[60] Padmavathi, R.; Senthilnathan, P.; Chodon, D. et al. (2006). Therapeutic effect of paclitaxel and propolis on lipid peroxidation and antioxidant system in 7,12 dimethyl benz(a)anthracene-induced breast cancer in female Sprague Dawley rats. Life Sci, 78: 2820-2825.

[61] Jasprica, D.; Mornar, A.; Debelijak, Z. et al. (2007). In vivo study of propolis supplementation effects on antioxidative status and red blood cells. J Ethnopharmacol, 110: 548-554.

\section{How to cite this article:}

Fathy, S. M. and Said, N. I. (2019). Immunomodulation and antigenotoxic effects of propolis in paclitaxel-treated rats. Egyptian Journal of Zoology, 72: 45-56 (DOI: 10.12816/ejz.2019.18937.1017). 


\section{التعديل المناعي والتأثيرات المضادة للسُمية الوراثية لصمغ النحل في الجِرذان المعاملة بالباكليتاكسيل}

\section{سماح ممدوح محمد فتحي، نهى إبراهيم سعيد سالم}

قسم علم الحيوان، كلية العلوم، جامعة الفيوم، الفيوم، جمهورية مصر العربية

هدفت الدراسة الحالية إلى معرفة التأثيرات المحتملة المعدلة للمناعة والمضادة للسُمية الور اثية لصمغ النحل في الجِرذان

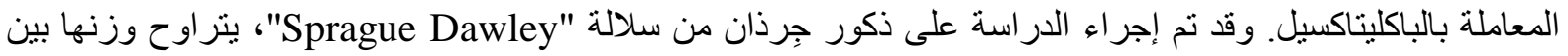

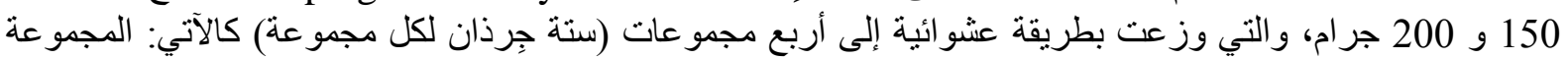

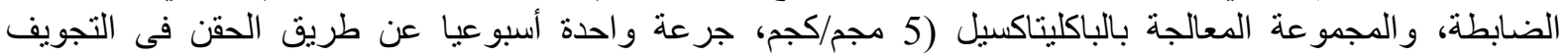

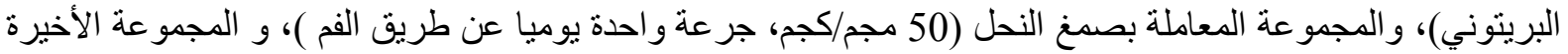

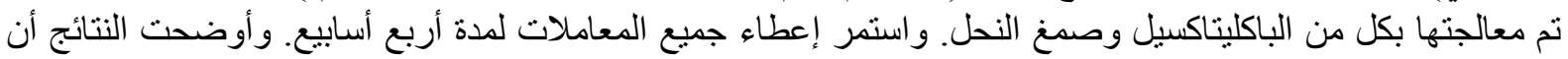

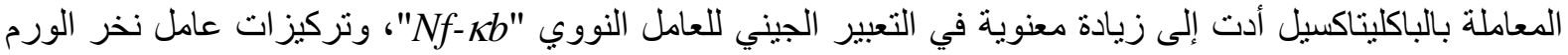

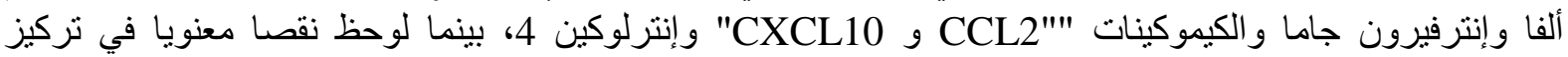

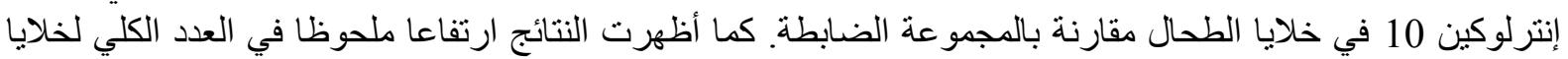

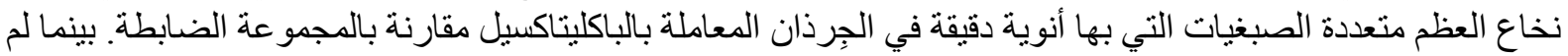

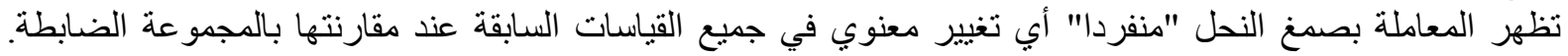

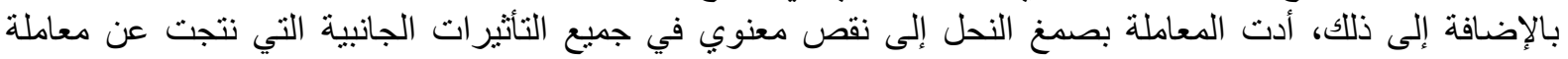

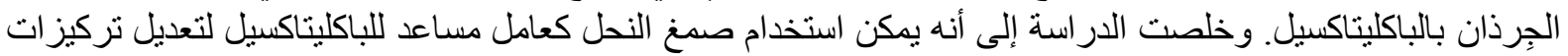

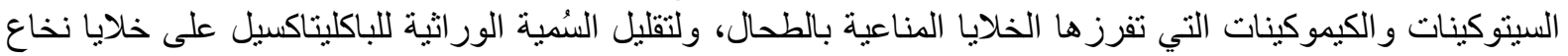

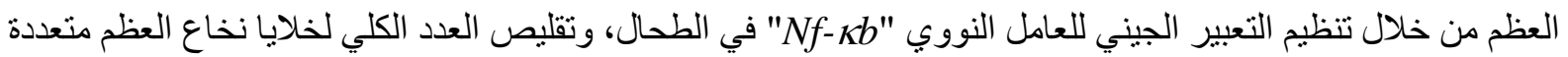

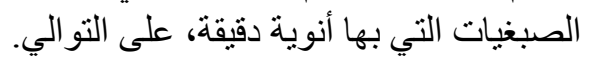

